\title{
Study on the Ecosystem Services of Urban Forests: Implications for Climate Change Mitigation in the Case of Adama City of Oromiya Regional State, Ethiopia
}

Hingabu Hordofa Koricho ( $\nabla$ hingabuh77@gmail.com )

Wuhan University of Technology https://orcid.org/0000-0001-6430-5098

\section{Ararsa Derese Seboka}

Hawassa University

\section{Fekadu Fufa}

Jimma University College of Engineering and Technology: Jimma University Institute of Technology

Tikabo Gebreyesus

Hawassa University

\section{Shaoxian Song}

Wuhan University of Technology - Mafangshan Campus: Wuhan University of Technology

\section{Research Article}

Keywords: Urban forest, Ecosystem service, Adama trees, Carbon sequestration, Pollutant

Posted Date: June 14th, 2021

DOI: https://doi.org/10.21203/rs.3.rs-183532/v1

License: (c) (i) This work is licensed under a Creative Commons Attribution 4.0 International License. Read Full License

Version of Record: A version of this preprint was published at Urban Ecosystems on October 16th, 2021. See the published version at https://doi.org/10.1007/s11252-021-01152-0. 


\section{Abstract \\ Background}

this study was conducted to explore the ecosystem services of urban forests in Adama city, central Ethiopia. Attempts were made to quantify the carbon storage and sequestration, air pollution removal and hydrological benefits of urban trees. The urban forest structure and composition of the city was surveyed and analyzed. The i-Tree Eco Model was employed to analyze the ecosystem services based on the current urban forests structure of the city.

\section{Results}

the result revealed that the urban trees of the Adama city stored a total of 116,000 tons of carbon. The tree species identified with higher $\mathrm{CO}_{2}$ sequestration per year were Melia azedarach (15\%), Eucalyptusglobulus (8\%), Carica papaya (T\%), and Delonix regia (6\%). In addition, $22 \%, 12 \%, 10 \%$ and $4 \%$ of carbon were stored by Eucalyptus globulus, Melia azedarach, Carica papaya and Delonix regia tree species respectively. Moreover, trees and shrubs species in the city removed about 188 thousand tons of air pollutants caused by $\mathrm{O}_{3}, \mathrm{CO}, \mathrm{NO}_{2}, \mathrm{PM} 2.5$ and $\mathrm{SO}_{2}$ per year. In Adama, 35\% of the urban trees' volatile organic compaound emissions were from Eucalyptus cinerea and Eucalyptus globulus. The monetary value of Adama urban forest in terms of carbon storage, carbon sequestration, and pollution removal was estimated to $43,781,3,121 \mathrm{yr}^{-1}$ and $320,915,596 \mathrm{USD}_{\mathrm{yr}}^{-1}$, respectively.

\section{Conclusions}

it was concluded that significant quantity of $\mathrm{CO}_{2}$ and air pollutants were found being removed by the exotic tree and shrub species. However, every plant species found in the city does not mean ecologically important due their VOC emitting nature. Thus, the results of the study are valuable in increasing the awareness of the decision making bodies, the public and any stakeholders of the eco-benefits of urban trees in the mitigation of climate changes.

\section{Introduction}

Human population growth and urbanization of the world have threatening the environment in various forms, such as elevated temperatures, increases air pollution and increases stormwater quantity, and decreases in storm water quality, which pose major environmental and public health problems in cities (Güneralp et al., 2020; Rydin et al., 2012). In this regard, urban forest ecosystem plays an important role in providing multiple service and environmental benefits to urban environment (Amoatey \& Sulaiman, 2020; Güneralp et al., 2020).

Ethiopia's urban centers have been urbanizing at rapid rate with a rate of about $4-5 \%$, and its urban population is expected to increase from time to time (Girma et al., 2019). The current phenomenon in Ethiopia has been associated with environmental problems in most cities. The major problems are urban sprawl, solid and liquid waste management; water, air, and noise pollution; illegal settlements and the degradation of open green areas (Mpofu, 2013). Developing countries like Ethiopia are experiencing the effects of climate change such as an increase in average temperature and change in rainfall patterns.

Urban green space is considered a mitigation interference for urban heat. While increasing the urban green space coverage is expected to reduce the urban heat, studies on the effects of urban green space formation have produced inconsistent results (Terfa et al., 2020). Quantification of ecosystem services provision by urban trees can be used to assess the actual and potential role of urban forests in providing environmental, social and economic benefits. 
Assessment of ecosystem services provided by the green spaces of Adama city is quiet scanty. The EU FP7 Climate change and Urban Vulnerability in Africa (CLUVA) project (www.cluva.eu) provided a foundation for the assessment of ecosystem services by the green spaces of the city. Apart from the above study, quantitative assessment of individual ecosystem services provided by urban forests of Adama city is generally lacking. As a result, information on ecosystem services from urban forests and green spaces are not available for use in the urban planning activities of the city.

There are several techniques and models that have been developed to quantify ecosystem services. These models include i-tree eco and i-tree streets (Mensah et al., 2017; Russo et al., 2014).

Such application of technologies to explore the ecosystem services of urban forests is extraordinary in Ethiopia. So far, there is no any i-tree Eco based ecosystem services assessment study conducted in Ethiopia. Thus, the main aim of this study was to assess the ecosystem service of urban forest of Adama city in terms of climate change mitigation. More specifically, the study was intended i) to assess carbon storage and sequestration potential of Adama city trees ii) to estimate the oxygen production and pollution removal by different species of Adama city trees and iii) assess the hydrological and functional values of trees in Adama city.

\section{Research Methods}

\section{Study Area}

This study was conducted in Adama city of Oromiya National Regional State, Central Ethiopia. Adama city is geographically situated between $8^{\circ} 32^{\prime} 24^{\prime \prime}$, latitude and $39^{\circ} 16^{\prime} 12^{\prime \prime}$ longitude at altitude of 1,712 meter a.s.l. (Fig. 1). The total area of the city was about $13,366.5$ ha and it is situated at about $99 \mathrm{~km}$ distance from Addis Ababa the capital city of Ethiopia. The annual average minimum and maximum temperature of the study area was 13 and $27^{\circ} \mathrm{C}$, respectively. The annual average rainfall is $837-1005.7 \mathrm{~mm}$ and its climate varies due to the great variation in altitude (Koricho et al., 2020). The total population of Adama city projection in 2018 was about 303,569 of which 150,228 are males and 153,341 are females.

\section{Research Design and Sampling}

A reconnaissance survey was conducted (from October to December, 2018) by a team of 5 people. The site assessment has done to observe the general plot information used to identify the plots and its general characteristics. In this work, trees and shrub information were used to estimate trees and shrubs leaf area/biomass, pollution removal, and volatile organic compound (VOC) emissions. Finally, tree information's used to estimate forest ecosystem value, carbon storage, carbon sequestration and hydrological functions of Adama city urban forest.

In this study, a total of 214 sample plots have established by using a simple random sampling method. As a general rule, 200 plots (one-tenth acre each) will yield a standard error of about $10 \%$ for an estimate of the entire city. As the number of plots increases, the standard error will be decrease; and therefore we were more confident to estimate for the population. With regard to the sample plot size, the standard plot size for an Eco analysis is a 0.1-acre circular plot with a radius of $11.16 \mathrm{~m}$ or 0.0407 hectares. The samples of plots were created directly in the Eco application using the random plots generator via the Google Maps function (Fig. 2).

The diameters of all identified trees and shrubs were measured at breast height (1.3 $\mathrm{m}$ above ground) using a diameter tape (5 $\mathrm{m}$ length). Diameter of individual trees were recorded to calculate basal area and relative basal area of plant species. Height of all sampling trees and shrubs were measured by Silva hypsometer.

The field data collection crews were typically located field plots using maps to indicate plot location. Aerial photographs and digital maps were used in order to locate plots and features. During random plots distribution in the city, the 
researchers faced a challenge of miss place placement of some plots; for example, some plot center has fallen in buildings, private land and the border of different land ownerships and land-use types; as a result the researcher's professional skills were used to shift the plot center into appropriate locations.

\section{Data collection and analysis}

In this study, the data were collected from sample plots with an area of 0.0407 ha (1/10 ac) that randomly laid in city areas of states and data were analyzed using the i-Tree Eco (formerly Urban Forest Effects (UFORE)) model (David J Nowak et al., 2008). The state plots were based on Forest Inventory Analysis national program plot design and data were collected as part of pilot projects testing FIA data collection in urban areas (Steenberg et al., 2016).

In this work, the i-Tree Eco suite was used to analyze the data. The i-Tree Eco is designed to use standardized field data from randomly located plots, as well as local hourly air pollution and meteorological data, to quantify urban forest structure, ecological function, and the associated value (Nowak, 1993; Soares et al., 2011).

Trees absorb carbon dioxide during photosynthesis, storing carbon and producing oxygen as a byproduct of photosynthesis. Carbon sequestration is the process of removing carbon from the atmosphere and storing it in a physical element (e.g., a tree). i-Tree Eco estimates carbon storage in trees, annual carbon sequestration, and emission of carbon via tree decomposition.

Carbon storage is estimated by multiplying tree biomass by 0.5 (Lamlom \& Savidge, 2006). To prevent carbon storage from overestimation for very large trees, total carbon storage is capped 7,500 kg of carbon in i-Tree Eco and forecast. To estimate annual gross carbon sequestration, the tree DBH is incrementally increased in the computer model based on an estimated annual growth rate. The carbon storage in the current year (year 0 ) is then contrasted with carbon storage in the next year (year 1) to estimate the annual sequestration. The cumulative leaf area in an urban forest canopy is an important variable influencing estimates of biomass, air pollution removal, carbon storage and sequestration, and other ecosystem services.

Leaf area is defined simply as the amount of surface area (one-sided) of leaves on a tree. Leaf area measurements are scaled up to cover an entire urban forest. The cumulative amount of leaf area per unit of projected ground surface area is known as the leaf area index and computed using Eq. (1)

$$
\mathrm{LAI}=\frac{\mathrm{LA}}{\mathrm{A}}
$$

Where $L A I=$ leaf area index; LA = leaf area $\left(\left(\mathrm{m}^{2}\right)\right.$; and $A=$ projected ground surface area $\left(\mathrm{m}^{2}\right)$.

For each tree found in the sample plots carbon storage, annual sequestration, oxygen production, pollutant removal and hydrological functions were estimated using biomass and growth equations. To estimate carbon storage and sequestration, the carbon data were standardized per unit of tree cover. The amount of oxygen produced is estimated from carbon sequestration based on atomic weights using Eq. (2) (Nowak et al., 2007).

$$
\text { Net } \mathrm{O}_{2} \text { Release }(\mathrm{kg} / \mathrm{yr})=\frac{\text { Net C Sequestration }(\mathrm{kg} / \mathrm{y}) * 32}{12}
$$

The VOC emissions depend on tree species, leaf biomass, air temperature, and other environmental factors. i-Tree Eco estimates the hourly emission of isoprene ( $\mathrm{C} 5 \mathrm{H} 8)$ and monoterpenes (C10 terpenoids), the two dominant VOC categories emitted by trees (Nowak et al., 2007). Standardized emissions are converted to actual emissions based on light and 
temperature correction factors and local meteorological data (Geron et al., 2006). VOC emission (E) in $\mu \mathrm{g} \mathrm{C/tree/h} \mathrm{for}$ isoprene and monoterpenes is estimated employing Eq. (3).

$E=B E \times B \times Y 3$

Where, $\mathrm{E}=\mathrm{VOC}$ emission in $\mu \mathrm{g} \mathrm{C} /$ tree $/ \mathrm{h} ; \mathrm{BE}=$ the base genus emission rate $\left(\mu \mathrm{g} \mathrm{C} / \mathrm{g}\right.$ leaf dry weight $/ \mathrm{h}$ at $30{ }^{0} \mathrm{C}$ and $\mathrm{PAR}$ flux of $1,000 \mu \mathrm{mol} / \mathrm{m}^{2} / \mathrm{s}$; and $B=$ species leaf dry weight biomass $(\mathrm{g})$ and $\mathrm{Y}=\mathrm{Y}=\exp [\beta(\mathrm{T}-\mathrm{Ts})]$

Where

$\mathrm{T}\left({ }^{\circ} \mathrm{K}\right)$ is leaf temperature, which is assumed to be air temperature, $\mathrm{TS}=303^{\circ} \mathrm{K}$, and $\beta=0.09$.

$\mathrm{i}$-Tree hydro is designed to assess hourly changes in water quantity and quality due to changes in tree and other land cover types within a watershed or nonwatershed area. i-Tree hydro calculates hourly interception, evapotranspiration, runoff, and other hydrologic values based on a semi-distributed, mechanistic rainfall-runoff computer model. Interception is simulated using an improved rutter methodology and evapotranspiration is simulated using improved penmanmonteith equation (Yang \& Endreny, 2013).

\section{Results}

\section{Structure of tree species of Adama city}

Trees covered about $20 \%$ of Adama city and provided 22.97 square kilometer of leaf area. In Adama urban trees, the most dominant species in terms of canopy cover and leaf area were Acacia albida, Casimiroa edulis, and Eucalyptus cinerea. The attributes of 20 tree species are presented in (Table 1). 
Table 1

The measurements and condition of some twenty common tree species

\begin{tabular}{|c|c|c|c|c|c|c|c|c|c|}
\hline Species & Frequency & DBH & Height & $\begin{array}{l}\text { Canopy } \\
\text { Cover } \\
\left(\mathrm{m}^{2}\right)\end{array}$ & $\begin{array}{l}\text { Tree } \\
\text { condition }\end{array}$ & $\mathrm{LA} / \mathrm{m}^{2}$ & $\begin{array}{l}\text { LB } \\
(\mathrm{kg})\end{array}$ & LAl & $\begin{array}{l}\text { BA } \\
\left(\mathrm{m}^{2}\right)\end{array}$ \\
\hline $\begin{array}{l}\text { Persia } \\
\text { americana }\end{array}$ & 31 & 4.27 & 18.67 & 8.16 & Good & 1288842.83 & 2.22 & 3.635 & 0.01 \\
\hline $\begin{array}{l}\text { Eucalyptus } \\
\text { globulus }\end{array}$ & 28 & 17.05 & 48.74 & 9.48 & Good & 2132693.33 & 6.27 & 4.51 & 0.29 \\
\hline Citrus medica & 16 & 8.16 & 22.77 & 12.51 & Excellent & 2629323.55 & 8.34 & 4.23 & 0.04 \\
\hline $\begin{array}{l}\text { Podocarpus } \\
\text { falcatus }\end{array}$ & 24 & 7.46 & 33.66 & 8.22 & Good & 2139573 & 3.67 & 5.06 & 0.04 \\
\hline $\begin{array}{l}\text { Eucalyptus } \\
\text { camaldulensis }\end{array}$ & 24 & 7.87 & 86.05 & 7.19 & Excellent & 1532058.90 & 4.55 & 4.94 & 0.05 \\
\hline Olea europea & 11 & 5.1 & 16.4 & 2.45 & Poor & 420873 & 0.72 & 3.9 & 0.01 \\
\hline $\begin{array}{l}\text { Acacia } \\
\text { abyssinica }\end{array}$ & 40 & 7.09 & 17.39 & 9.14 & Fair & 1633149.38 & 9.06 & 3.88 & 0.05 \\
\hline $\begin{array}{l}\text { Eucalyptus } \\
\text { grandis }\end{array}$ & 14 & 7.91 & 36.53 & 10.28 & Fair & 3051491.62 & 8.09 & 6.35 & 0.04 \\
\hline $\begin{array}{l}\text { Cordia } \\
\text { africana }\end{array}$ & 16 & 7.42 & 18.7 & 11.19 & Good & 2242403.61 & 3.85 & 3.77 & 0.03 \\
\hline $\begin{array}{l}\text { Mangifera } \\
\text { indica }\end{array}$ & 32 & 5.88 & 18.88 & 6.14 & Good & 1015153.93 & 1.74 & 3.75 & 0.02 \\
\hline $\begin{array}{l}\text { Melia } \\
\text { azedarach }\end{array}$ & 119 & 8.11 & 18.39 & 5.32 & Good & 1000504.31 & 1.71 & 3.88 & 0.05 \\
\hline Citrus sinensis & 20 & 4.04 & 13.61 & 4.24 & Good & 788165.76 & 2.25 & 4.225 & 0.01 \\
\hline Carica papaya & 55 & 9.10 & 17.71 & 3.83 & Good & 647577.96 & 1.11 & 3.83 & 0.01 \\
\hline Delonix regia & 33 & 10.44 & 36.13 & 13.99 & Excellent & 2468825.23 & 4.24 & 4.23 & 0.07 \\
\hline $\begin{array}{l}\text { Grevillea } \\
\text { robusta }\end{array}$ & 28 & 7.07 & 28.85 & 7.46 & Good & 1997406.92 & 5.57 & 5.38 & 0.04 \\
\hline $\begin{array}{l}\text { Eucalyptus } \\
\text { cinerea }\end{array}$ & & 8.37 & 75.68 & 16.65 & Good & 3438168.75 & 10.21 & 4.7 & 0.04 \\
\hline Acacia tortilis & 38 & & 16.97 & 13.57 & Fair & 2169479.26 & 12.04 & 3.48 & 0.02 \\
\hline $\begin{array}{l}\text { Leucaena } \\
\text { leucocephala }\end{array}$ & 35 & 4.62 & 18.05 & 4.65 & Excellent & 736851.62 & 1.26 & 4.26 & 0.01 \\
\hline $\begin{array}{l}\text { Casimiroa } \\
\text { edulis }\end{array}$ & 15 & 9.12 & 30.66 & 25.30 & Good & 5150434.17 & 8.85 & 5 & 0.05 \\
\hline Acacia albida & & 14.42 & 31.02 & 25.13 & Good & 5531648.04 & 30.69 & 4.78 & 0.14 \\
\hline Total & & 153.57 & 604.93 & 204.93 & & 41990991.61 & 126.48 & 87.82 & 1.13 \\
\hline
\end{tabular}


In 2018, trees in Adama city emitted about 52 tons of volatile organic compounds (VOCs) per year of which 34 tons was isoprene and 18 tons was monoterpenes. The amount of emissions from the trees varied based on species characteristics (e.g. some genera such as Grevellia robusta was high isoprene emitter) and amount of leaf biomass. In Adama city, $35 \%$ of the urban trees' VOC emissions was by Eucalyptus cinerea and Eucalyptus globulus. These VOCs are precursor chemicals to ozone formation (Table 3).

Table 3

Estimates of VOC removal by common woody species of Adama city

\begin{tabular}{|c|c|c|c|}
\hline Species Name & Monoterpene (kg/yr.) & Isoprene (kg/yr.) & Total VOCs (kg/yr.) \\
\hline Persea americana & 95.25 & 3.40 & 98.66 \\
\hline Eucalyptus globulus & 1216.49 & 6091.97 & 7308.51 \\
\hline Schinus molle & 323.91 & 0.00 & 323.91 \\
\hline Acacia torulosa & 513.47 & 3.67 & 517.14 \\
\hline Eucalyptus camaldulensis & 757.68 & 3794.21 & 4551.89 \\
\hline Acacia abyssinica & 2513.26 & 17.96 & 2531.27 \\
\hline Eucalyptus grandis & 786.17 & 3936.91 & 4723.08 \\
\hline Mangifera indica & 291.71 & 0.00 & 291.70 \\
\hline Pinus patula & 174.49 & 1.27 & 175.77 \\
\hline Citrus sinensis & 135.49 & 2.22 & 137.76 \\
\hline Acacia seyal & 222.21 & 1.59 & 223.80 \\
\hline Ficus elastica & 131.36 & 3228.48 & 3359.89 \\
\hline Grevillea robusta & 72.16 & 7.76 & 79.92 \\
\hline Eucalyptus cinerea & 1487.78 & 7450.62 & 8938.40 \\
\hline Acacia tortuosa & 350.17 & 2.49 & 352.71 \\
\hline Acacia tortilis & 3171.69 & 22.68 & 3194.42 \\
\hline Acacia albida & 1915.47 & 13.69 & 1929.17 \\
\hline Casimiroa edulis & 445.06 & 6.58 & 451.64 \\
\hline Eucalyptus globoidea & 451.96 & 2263.28 & 2715.25 \\
\hline Total & 15447.31 & 26855.25 & 42302.84 \\
\hline
\end{tabular}

\section{Carbon Storage and Sequestration}

Trees reduce the amount of carbon in the atmosphere by sequestering carbon in new growth every year. The gross carbon sequestration of Adama city trees was about 8,291 thousand tons of carbon per year with an associated value of 31,134 USD. Net carbon sequestration in the urban forest was about 7,474 thousand tons. The most common species that are known for the greater share of carbon sequestration in the study area forest are listed in Table 2. In particular, the tree species such as Melia azedarach, Eucalyptus globulus, Carica papaya and Delonix regia sequestered the most percentage of carbon which were approximately $15,8,7$ and $6 \%$ of all annually sequestered carbon respectively (Fig. 3). 
Trees in Adama urban forests were estimated to store 116,000 tons of carbon (437,994.7 USD). Of the species sampled, Eucalyptus globulus, Melia azedarach, Carica papaya and Delonix regia stored the most approximately $22,12,10$ and $4 \%$ of all stored carbon respectively (Table 2 ).

Table 2

Carbon storage and sequestration potential of common woody species of Adama urban forest.

\begin{tabular}{|c|c|c|c|c|c|}
\hline Species & $\begin{array}{l}\text { No of } \\
\text { trees }\end{array}$ & $\begin{array}{l}\text { Carbon storage } \\
\text { (ton/yr) }\end{array}$ & $\begin{array}{l}\text { Co2 } \\
\text { equivalent(ton) }\end{array}$ & $\begin{array}{l}\text { Carbon sequestratoin } \\
\text { (ton/yr) }\end{array}$ & $\begin{array}{l}\text { Co2 } \\
\text { equivalent(ton) }\end{array}$ \\
\hline Acacia abyssinica & 26099 & 6086.60 & 22319.60 & 321.30 & 1178.22 \\
\hline Acacia albida & 5872 & 3147.70 & 11542.60 & 251.39 & 921.84 \\
\hline Melia azedarach & 77643 & 14273.62 & 52341.40 & 1220.63 & 4476.04 \\
\hline $\begin{array}{l}\text { Casuarina } \\
\text { cunninghamiana }\end{array}$ & 5220 & 5544.41 & 20331.40 & 51.27 & 188.02 \\
\hline Carica papaya & 35886 & 11018.11 & 40403.40 & 607.28 & 2226.91 \\
\hline Delonix regia & 21531 & 4844.54 & 17764.9 & 518.38 & 1900.90 \\
\hline Eucalyptus cinerea & 13702 & 2260.97 & 8291 & 232.21 & 851.51 \\
\hline Eucalyptus globulus & 18269 & 25676.41 & 94155.4 & 612.23 & 2245.04 \\
\hline Ficus sur & 1957 & 986.93 & 3619.10 & 47.36 & 173.66 \\
\hline Ficus sycomorus & 3915 & 2892.47 & 10606.7 & 243.8 & 894.03 \\
\hline Ficus vasta & 652 & 5001.59 & 18340.8 & 14.98 & 54.95 \\
\hline Grevillea robusta & 18269 & 2670.20 & 1176.82 & 320.92 & 1176.82 \\
\hline Podocarpus falcatus & 15659 & 2114.66 & 952.95 & 259.87 & 952.95 \\
\hline Acacia tortilis & 24794 & 1854.20 & 6799.20 & 277.86 & 1018.91 \\
\hline Casimiroa edulis & 9787 & 1572.10 & 5765.00 & 217.06 & 795.96 \\
\hline Citrus medica & 10439 & 1640.8 & 6016.80 & 179.74 & 659.12 \\
\hline Ficus elastica & 4567 & 1996.3 & 7320.30 & 169.20 & 620.46 \\
\hline Persea americana & 20226 & 663.50 & 2433.10 & 138.63 & 508.34 \\
\hline Total & 314487 & 94245.11 & 330180.47 & 5684.11 & 20843.68 \\
\hline
\end{tabular}

\section{Air Pollution Removal by Urban Trees}

Urban pollution removal capacities of each urban tree species are presented in (Fig. 4). It is estimated that trees and shrubs removed 188 thousand tons of air pollution (ozone $\left(\mathrm{O}_{3}\right)$, carbon monoxide $(\mathrm{CO})$, nitrogen dioxide $\left(\mathrm{NO}_{2}\right)$, particulate matter less than 2.5 microns (PM2.5), and sulfur dioxide $\left(\mathrm{SO}_{2}\right)$ ) per year with an associated value of 686,519,156.80 USD.

\section{Hydrological benefits of urban trees}

Urban forests as a whole have important roles throughout the hydrological cycle. Tree crowns intercept rain and reduce the amount of water reaching the pervious or impervious surfaces below. This can increase evapotranspiration and transpiration of urban forests. The total leaf area of Adama urban forest was 2,298 hectare. The potential 
evapotranspiration of Adama urban forest was about 5,313,800.51 $\mathrm{m}^{3}$ per year, whereas the transpiration potential was estimated to $1,371,715.79 \mathrm{~m}^{3}$ per year. In (Table 4) presents the hydrological benefits of 18 tree species of Adama city.

Table 4

Hydrological benefits of 18 tree species of Adama city

\begin{tabular}{|c|c|c|c|c|}
\hline Species Name & Number of Trees & Leaf Area/ha & Potential Evapotranspiration & Transpiration \\
\hline Ficus sur & 1957 & 35.90 & 33603.48 & 8674.47 \\
\hline Ficus vasta & 652 & 2.64 & 2468.71 & 637.28 \\
\hline Citrus medica & 10439 & 155.71 & 145742.66 & 37622.32 \\
\hline Podocarpus falcatus & 15659 & 190.06 & 177895.34 & 45922.28 \\
\hline Eucalyptus cinerea & 13702 & 267.24 & 250134.06 & 64570.14 \\
\hline Casimiroa edulis & 9787 & 285.95 & 267646.93 & 69090.95 \\
\hline Acacia tortilis & 24794 & 305.14 & 285602.841 & 73726.13 \\
\hline Acacia abyssinica & 26099 & 241.79 & 226313.19 & 58420.97 \\
\hline Azadirachta indica & 77643 & 440.68 & 412470.73 & 106476.07 \\
\hline Carica papaya & 35886 & 131.83 & 123391.86 & 31852.64 \\
\hline Eucalyptus globulus & 18269 & 218.51 & 204522.18 & 52795.79 \\
\hline Grevillea robusta & 18269 & 207.00 & 193748.11 & 50014.55 \\
\hline Persea americana & 20226 & 147.88 & 138415.90 & 35730.97 \\
\hline Delonix regia & 21531 & 301.55 & 282243.28 & 72858.88 \\
\hline Acacia albida & 5872 & 184.28 & 172482.74 & 44525.06 \\
\hline Casuarina cunninghamiana & 5220 & 24.65 & 23074.77 & 5956.57 \\
\hline Ficus elastica & 4567 & 611.96 & 572784.51 & 147859.81 \\
\hline Ficus sycomorus & 3915 & 225.14 & 210724.74 & 54396.93 \\
\hline Total & 14487 & 3977.91 & 42075.98 & 961131.82 \\
\hline
\end{tabular}

\section{Eco benefit of Adama urban trees}

The summary of ecosystem value that include number of trees, carbon storage and sequestration, pollution removal, and structural value of woody species of Adama urban forest were estimated and summarized in (Table 5).

Table 5

The summary of monetary value of Adama urban trees

\begin{tabular}{|lllllll|}
\hline Trees & \multicolumn{2}{l}{ Carbon Storage } & \multicolumn{2}{l|}{ Gross Carbon Sequestration } & \multicolumn{2}{l|}{ Pollution Removal } \\
\hline No & Ton & USD & Ton/yr. & USD/yr & Ton/yr & USD/yr. \\
\hline 525235 & 116280 & 437,691 & 8291 & 31,209 & 89445 & $320,915,596$ \\
\hline
\end{tabular}


Carbon storage and gross carbon sequestration values were calculated based on the price of 3.76 USD per ton. Also, the pollution removal value was calculated based on the prices of 1,041.15 USD per ton (CO), 7,330.42 USD per ton $\left(\mathrm{O}_{3}\right)$, 7,330.42 USD per ton $\left(\mathrm{NO}_{2}\right), 1,794.60$ USD per ton $\left(\mathrm{SO}_{2}\right), 4,894.18$ USD per ton $\left(\mathrm{PM}_{2.5}\right)$.

\section{Discussions}

This study estimated the quantity of the carbon stored and sequestered by urban trees in Adama city of central Ethiopia. The result of carbon sequestration and storage of Adama city was appeared higher than carbon assessment work conducted in agroforestry practices of southeastern Ethiopia (Bikila \& Zebene, 2019). Besides, The resulted reported by Stoffberg et al.(2010) in the city of Tshwane Metropolitan Municipality in South Africa estimated that 54,630 tonnes carbon were sequestered by urban forests (Stoffberg et al., 2010). However, the amount of carbon stored and sequestered in Adama urban trees was lower than result indicated in the study conducted in urban areas of Pune, India; the estimate of carbon storage was between 600 and 900 million tones (Ambedkar, 2010). Also, the current result was higher than the result reported by Siraj, (2019), regarding carbon storage and sequestration of Chilimo-Gaji forest; which was estimated to be 506.7 ton and 1859.45 tons per year respectively (Siraj, 2019). The annual carbon storage and sequestration of Addis Ababa city, Ethiopia were higher than that of Adama city which is also a city in Ethiopia (Woldegerima et al., 2017). This could be due to tree species that grow in Addis Ababa city which is colder than Adama city are diffirent in their characteristics. This comparison showed that the annual carbon storage and sequestration of cites were higher than that of Adama city of Ethiopia except the annual carbon sequestration of Jersey city which was less than Adama city.

In this result, the amount of annual Volatile Organic Carbon (VOC) removal was lower than the report of study conducted in Scotlandville's trees which yearly produce 8.91 tons of monoterpene, 125.53 tons of isoprene, and produce 134.43 tons of volatile organic compounds (VOCs); that may contribute to ozone formation (David J. Nowak et al., 2014; David J Nowak et al., 2008).

In Adama urban forest trees such as Acacia tortilis, Melia azedarach and Ficus elastica have higher potential evapotranspiration and transpiration (Table 4). Similar, Xiao and McPherson (2016) reported that trees in urban areas can increase the return of runoff to the atmosphere through transpiration, providing associated air cooling benefits. Furthermore, according to the study of Gwynns Falls watershed in Baltimore indicated that heavily forested areas can reduce total runoff by as much as $26 \%$ and increase low-flow runoff by up to $13 \%$ compared with non-tree areas in existing land cover and land use conditions (Banerjee et al., 2013; David J. Nowak \& Dwyer, 2007). Studies have also reported that tree cover over pervious surfaces reduced total runoff by as much as $40 \%$; while tree canopy cover over impervious surfaces had a limited effect on runoff (Song et al., 2020).

The Adama urban forest in terms of monetary value have presented in the result section (Table 5). The outcome of current study was compared with the study conducted in city of Baton Rouge the annual monetary value of urban forest service were lower, in terms of Carbon storage (\$6.2 million/year), Carbon sequestration (\$41.0 million) and pollution removal (\$1.1 million/year).

In general, this work has tried to quantify the ecosystem service value of Adama city of Ethiopia which will help for further urban forest development work and government intervention in terms of policy and awareness creation. Further researches should be conducted assess and evaluate the ecosystem service value of urban trees in several urban green infrastructures and comparing with different cities in the country. This will sensitize cities to learn and compute in urban forest development to enhance the ecosystem value of trees.

\section{Conclusions}


Urban trees and forests have positive effect on human health and well-being through improving air quality and reducing greenhouse gases, mainly through lowering air temperatures and energy use and through direct pollution removal and carbon sequestration. Although the current greening coverage and management practice is contributing significant amount of $\mathrm{CO}_{2}$ sequestration and pollutant removal, further greenery expansion in the city would help to have sustainable urbanization trend in the city and its outskirts. The incorporation of adequate tree coverage into the built-up environment and proper management practices would expected to increase the pollutants and carbon absorption.

Understanding the value of an urban forest can give decision makers a better understanding of urban tree management. Exotic tree and shrub species are the predominant vegetation of the Adama city. As a result, the higher carbon sequestration and pollutant removal were found with most introduced ornamental trees and shrubs. However, all trees and shrubs species are not positively contribute to the environmental remedy. Some species were found diversely affecting the environment due to the fact that significant amount of VOC emission and formation of pollutants.

These results provide baseline information for management recommendations to maximize the ecological benefits provided by trees. By understanding the effects of trees and forests on the atmospheric environment, urban forest managers and policy makers can decide on the policy and strategic planning of urban greening. Subsequently, it will help for designing appropriate and healthy vegetation structure in cities to improve air quality and consequently human health and well-being for current and future generations.

\section{Abbreviations}

SE: Standard Error; USD: US Dollar; yr: year; VOC: Volatile Organic Carbon; kg: kilogram; $\mathrm{CO}_{2}$ : Carbon dioxide; $\mathrm{m}^{2}$ : meter squer; $\mathrm{DBH}$ : Diameter at Breast Height; $\mathrm{SO}_{2}$ : Sulfur dioxide; $\mathrm{O}_{3}$ : Ozone; $\mathrm{CO}$ : Carbon mono oxide; $\mathrm{NO}_{2}$ : Nitrogen dioxide; $\mathrm{PM}_{2.5}$ : Particulate Matter less than 2.5 microns.

\section{Declarations}

\section{Acknowledgment}

The authors acknowledge the experts of Adama city urban greening and beautification department (Mr. Abu Regasa, Mr. Adugna Muleta, Mr. Girma Godana, and Mr. Yadesa Kacha) for their assistance in facilitating the fieldwork. Also the authors are grateful to Dr. Mesfin Asefa a Mayor of Adama city administration and as well as Wuhan University of Technology, China for financial and other necessary support during our study.

\section{Author's Contributions}

Mr. Hingabu Hordofa: Contributed in designing the research idea, data collection, report writing and data analysis and guiding the overall paper work:

Mr. Ararsa Derese: Participated in data analysis, interpretation and report writing:

Dr. Fekadu Fufa: Participated in designing method and structuring report:

Professor Shaoxian Song: Participated in designing method, structuring report and guiding the overall paper work.

\section{Funding}

This work was supported by the Adama city administration [\$1500]; Wuhan University of Technology [\$1000] are greatly acknowledged. 
Availability of data and materials

The data set generated for the study area is available from the corresponding author on reasonable request.

\section{Ethics approval and consent to participate}

The subject has no ethical risk.

\section{Consent for publication}

The subject matter has no ethical risk.

\section{Computing interest}

The authors declares that they have no competing interests.

\section{References}

1. Ambedkar B (2010) Sequestered standing carbon stock in selective tree species grown in University campus at Sequestered standing carbon stock in selective tree species grown in University campus at Aurangabad, Maharashtra. International Journal of Engineering Science Technology 2(July):3003-3007

2. Amoatey P, Sulaiman H (2020) Quantifying carbon storage potential of urban plantations and landscapes in Muscat, Oman. Environ Dev Sustain 22(8):7969-7984

3. Banerjee O, Crossman ND, de Groot RS (2013) Ecological Processes, Functions and Ecosystem Services: Inextricable Linkages between Wetlands and Agricultural Systems. Ecosystem Services in Agricultural and Urban Landscapes, January 2018, 16-27

4. Bikila M, Zebene A (2019) Carbon Sequestration in Agroforestry Practices with relation to other Land Uses around Dallo Mena Districts of Bale Zone, Southeastern Ethiopia. Academic Research Journal of Agricultural Science Research 7(5):218-226

5. Geron C, Owen S, Guenther A, Greenberg J, Rasmussen R, Hui Bai J, Li QJ, Baker B (2006) Volatile organic compounds from vegetation in southern Yunnan Province, China: Emission rates and some potential regional implications. Atmos Environ 40(10):1759-1773

6. Girma Y, Terefe H, Pauleit S, Kindu M (2019) Urban green spaces supply in rapidly urbanizing countries: The case of Sebeta Town, Ethiopia. Remote Sensing Applications: Society Environment 13:138-149

7. Güneralp B, Reba M, Hales BU, Wentz EA, Seto KC (2020) Trends in urban land expansion, density, and land transitions from 1970 to 2010: A global synthesis. Environmental Research Letters, 15(4)

8. Koricho HH, Seboka AD, Song S (2020) Assessment of the structure, diversity, and composition of woody species of urban forests of Adama city, Central Ethiopia. Arboricultural Journal 00(00):1-12

9. Lamlom SH, Savidge RA (2006) Carbon content variation in boles of mature sugar maple and giant sequoia. Tree Physiol 26(4):459-468

10. Mensah S, Veldtman R, Assogbadjo AE, Ham C, Glèlè Kakaï R, Seifert T (2017) Ecosystem service importance and use vary with socio-environmental factors: A study from household-surveys in local communities of South Africa. Ecosystem Services, 23(February 2016), 1-8

11. Mpofu TPZ (2013) Environmental challenges of urbanization: A case study for open green space management. Research Journal of Agricultural Environmental Management 2(4):105-110

12. Nowak DJ (1993) Compensatory value of an urban forest: An application of the tree-value formula. J Arboric 19(3):173-177 
13. Nowak DJ (1996) Estimating leaf area and leaf biomass of open-grown deciduous urban trees. Forest Science 42(4):504-507

14. Nowak DJ, Dwyer JF (2007) Understanding the Benefits and Costs of Urban Forest Ecosystems. In: Urban and Community Forestry in the Northeast. Springer Netherlands, pp 25-46

15. Nowak DJ, Hirabayashi S, Bodine A, Greenfield E (2014) Tree and forest effects on air quality and human health in the United States. Environ Pollut 193(October):119-129

16. Nowak DJ, Hoehn R, Crane DE (2007) Oxygen production by urban trees in the United States. Arboriculture Urban Forestry 33(3):220-226

17. Nowak DJ, Crane DE, Stevens JC, Hoehn RE, Walton JT, Bond J (2008) A Ground-Based Method of Assessing Urban Forest Structure and Ecosystem Services. In Aboriculture \& Urban Forestry. 34(6): 347-358. (Vol. 34, Issue 6)

18. Russo A, Escobedo FJ, Timilsina N, Schmitt AO, Varela S, Zerbe S (2014) Assessing urban tree carbon storage and sequestration in Bolzano, Italy. International Journal of Biodiversity Science Ecosystem Services Management 10(1):54-70

19. Rydin Y, Bleahu A, Davies M, Dávila JD, Friel S, De Grandis G, Groce N, Hallal PC, Hamilton I, Howden-Chapman P, Lai KM, Lim CJ, Martins J, Osrin D, Ridley I, Scott I, Taylor M, Wilkinson P, Wilson J (2012) Shaping cities for health: Complexity and the planning of urban environments in the 21st century. The Lancet 379(9831):2079-2108

20. Siraj M (2019) Forest carbon stocks in woody plants of Chilimo-Gaji Forest, Ethiopia: Implications of managing forests for climate change mitigation. South African Journal of Botany 127:213-219

21. Soares AL, Rego FC, McPherson EG, Simpson JR, Peper PJ, Xiao Q (2011) Benefits and costs of street trees in Lisbon, Portugal. Urban Forestry Urban Greening 10(2):69-78

22. Song P, Guo J, Xu E, Mayer AL, Liu C, Huang J, Tian G, Kim G (2020) Hydrological effects of urban green space on stormwater runoff reduction in Luohe, China. Sustainability (Switzerland) 12(16):1-20

23. Steenberg JWN, Millward AA, Nowak DJ, Robinson PJ, Ellis A (2016) Forecasting Urban Forest Ecosystem Structure, Function, and Vulnerability Forecasting Urban Forest Ecosystem Structure, Function, and Vulnerability.

Environmental Management, June 2018

24. Stoffberg GH, van Rooyen MW, van der Linde MJ, Groeneveld HT (2010) Carbon sequestration estimates of indigenous street trees in the City of Tshwane, South Africa. Urban Forestry Urban Greening 9(1):9-14

25. Terfa BK, Chen N, Zhang X, Niyogi D (2020) Urbanization in small cities and their significant implications on landscape structures: The case in Ethiopia. Sustainability (Switzerland) 12(3):1-19

26. Woldegerima T, Yeshitela K, Lindley S (2017) Ecosystem services assessment of the urban forests of Addis Ababa, Ethiopia. Urban Ecosystems 20(3):683-699

27. Yang Y, Endreny TA (2013) Watershed hydrograph model based on surface flow diffusion. Water Resour Res 49(1):507-516

\section{Figures}




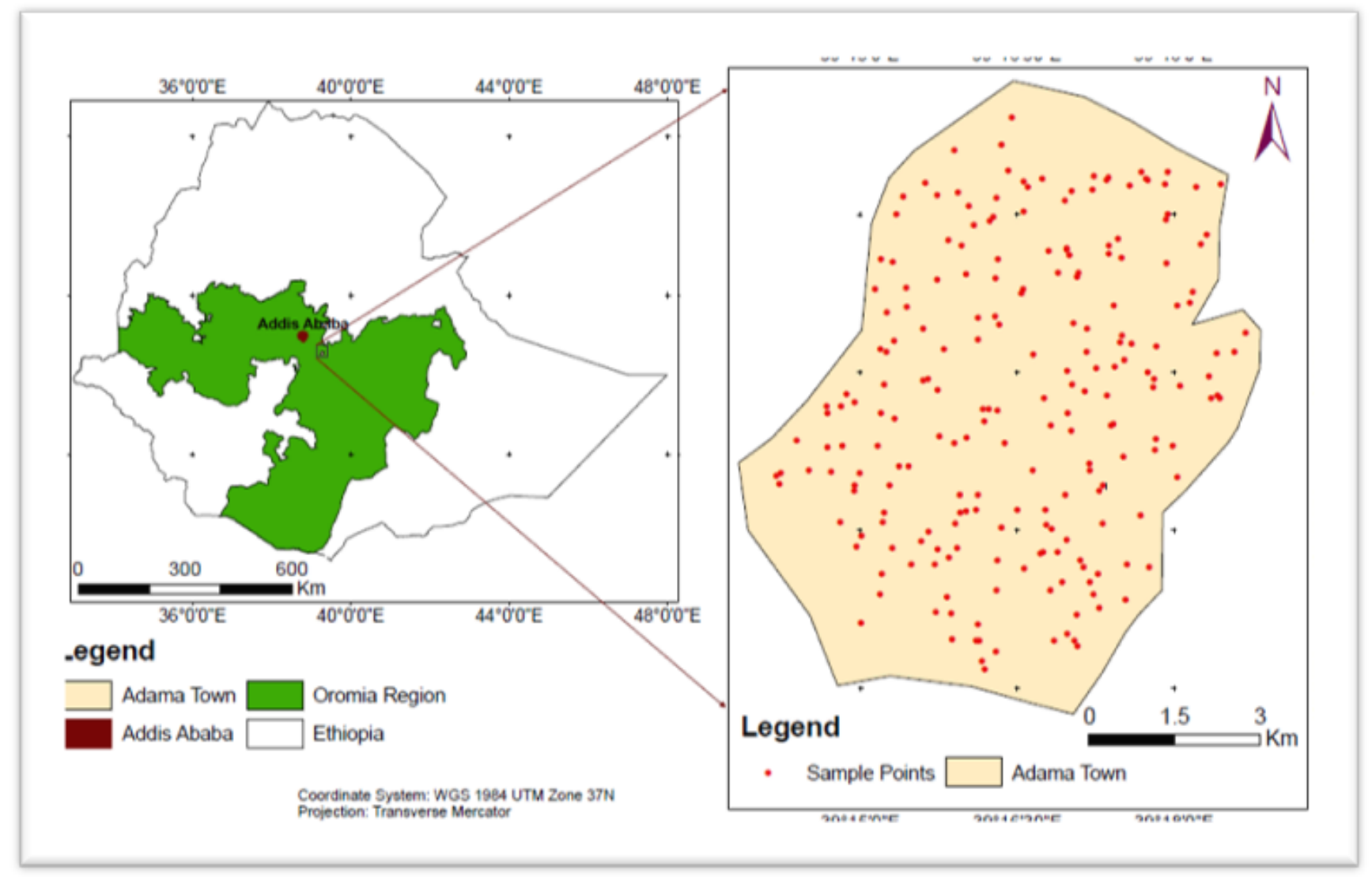

Figure 1

Location map of the study area.

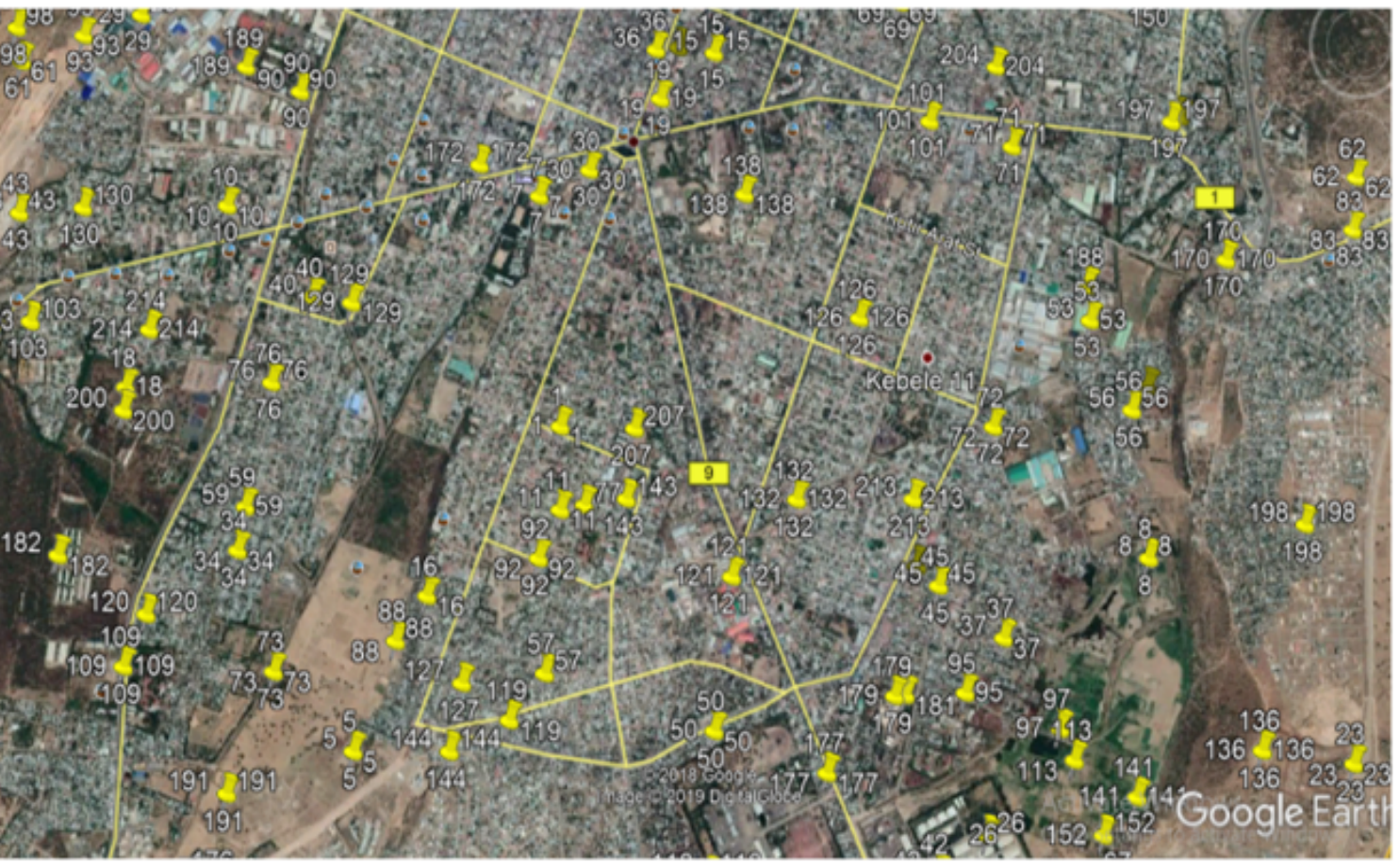

Figure 2 


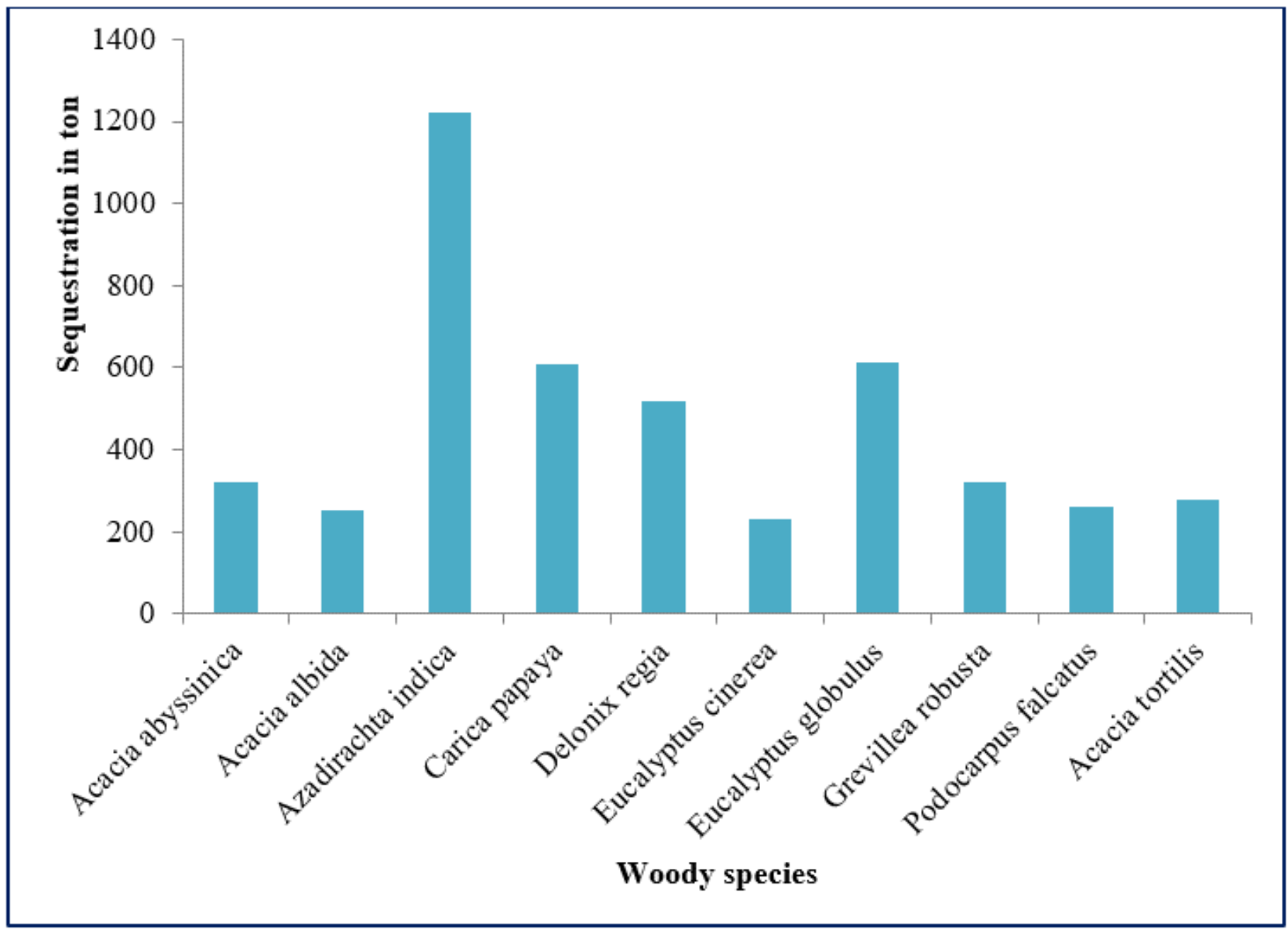

Figure 3

Estimated annual gross carbon sequestration (points) and value (bars) by urban tree species of Adama city

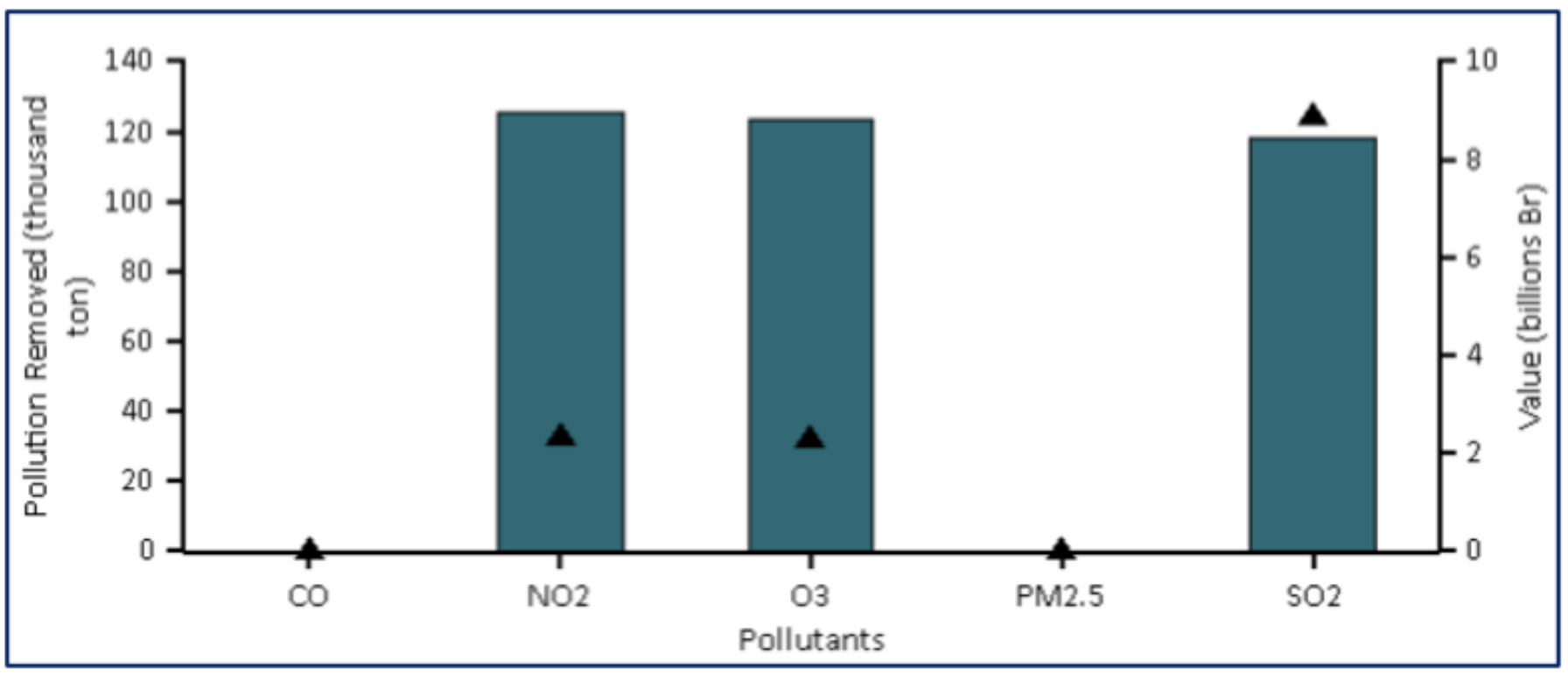

Figure 4

Annual pollution removal (points) and value (bars) by urban trees of Adama city 